\title{
SPRINGER SERIES ON
}

ENVIRONMENTAL MANAGEMENT

\author{
BRUCE N. A NDERSON \\ ROBERT W. HOWARTH \\ LAWRENCE R. WALKER
}

Series Editors 


\section{Springer Series on Environmental Management \\ Volumes published since 1989}

The Professional Practice of

Environmental Management

(1989)

R.S. Dorney and L. Dorney (eds.)

Chemical in the Aquatic

Environment: Advanced Hazard

Assessment (1989)

L. Landner (ed.)

Inorganic Contaminants of Surface Water: Research and Monitoring Priorities (1991)

J.W. Moore

Chernobyl: A Policy Response Study (1991)

B. Segerstahl (ed.)

Long-Term Consequences of Disasters: The Reconstruction of Friuli, Italy, in Its International Context, 1976-1988 (1991)

R. Geipel

Food Web Management: A Case Study of Lake Mendota (1992) J.F. Kitchell (ed.)

Restoration and Recovery of an Industrial Region: Progress in Restoring the Smelter-Damaged Landscape near Sudbury, Canada (1995)

J.M. Gunn (ed.)

Limnological and Engineering Analysis of a Polluted Urban Lake: Prelude to Environmental Management of Onondaga Lake, New York (1996)

S.W. Effler (ed.)

Assessment and Management of Plant Invasions (1997)

J.O. Luken and J.W. Thieret (eds.)
Marine Debris: Sources, Impacts, and Solutions (1997)

J.M. Coe and D.B. Rogers (eds.)

Environmental Problem Solving:

Psychosocial Barriers to Adaptive Change (1999)

A. Miller

Rural Planning from an

Environmental Systems

Perspective (1999)

F.B. Golley and J. Bellot (eds.)

Wildlife Study Design (2001)

M.L. Morrison, W.M. Block, M.D.

Strickland, and W.L. Kendall

Selenium Assessment in Aquatic Ecosystems: A Guide for Hazard Evaluation and Water Quality

Criteria (2002)

A.D. Lemly

Quantifying Environmental

Impact Assessments Using Fuzzy

Logic (2005)

R.B. Shephard

Changing Land Use Patterns in the Coastal Zone: Managing Environmental Quality in Rapidly Developing Regions (2006) G.S. Kleppel, M.R. DeVoe, and M.V. Rawson (eds.)

The Longleaf Pine Ecosystem:

Ecology, Silviculture, and

Restoration (2006)

S. Jose, E.J. Tokela, and D.L. Miller (eds.)

Linking Restoration and Ecological Succession (2007)

L.R. Walker, J. Walker, R.J. Hobbs (eds.) 
Lawrence R. Walker

Joe Walker

Richard J. Hobbs

Editors

\section{Linking Restoration and Ecological Succession}

照 Springer 
Editors:

Lawrence R. Walker

Department of Biological Sciences

University of Nevada Las Vegas

Las Vegas, NV 89154

USA

walker@unlv.nevada.edu

\section{Joe Walker}

CSIRO Land and Water

PO Box 1666

Canberra ACT 2611

Australia

joe.walker@csiro.au
Richard J. Hobbs

School of Environmental Science

Murdoch University

Murdoch WA 6150

Australia

r.hobbs@murdoch.edu.au
Series Editors:

Bruce N. Anderson

Planreal Australasia

Keilor, Victoria 3036

Australia

bnanderson@compuserve.com
Robert W. Howarth

Program in Biogeochemistry and Environmental Change

Cornell University, Corson Hall

Ithaca, NY 14853

USA

rwh2@cornell.edu
Lawrence R. Walker

Department of Biological Sciences

University of Nevada Las Vegas

Las Vegas, NV 89154

USA

walker@unlv.nevada.edu

Cover Illustration: The photo shows several stages in the restoration of areas mined for phosphate on Christmas Island situated in the Indian Ocean.

1. The rainforest type in the background is complex mesophyll vine forest and the canopy height is about $35 \mathrm{~m}$.

2. The closed canopy vegetation in the middle distance is natural regrowth (i.e., a secondary succession) after about 25 years on areas cleared for phosphate mining - the canopy is dominated by 15 to $20 \mathrm{~m}$ tall Macaranga tanarius (Euphorbiaceae), a common early successional tree on disturbed sites in the SE Asia/Pacific region.

3. The vegetation in the foreground was planted onto the mined area and is one year old. Macaranga tanarius (the largeleafed plant) is a major component of the rehabilitation and is used to mimic the early stages of natural succession. Photo by Paul Reddell.

Library of Congress Control Number: 2006927706

ISBN-10: 0-387-35302-X

ISBN-13: 978-0387-35302-9

e-ISBN-10: 0-387-35303-8

e-ISBN-13: 987-0387-35303-6

Printed on acid-free paper.

(C) 2007 Springer Science+Business Media, LLC

All rights reserved. This work may not be translated or copied in whole or in part without the written permission of the publisher (Springer Science+Business Media, LLC, 233 Spring Street, New York, NY 10013, USA), except for brief excerpts in connection with reviews or scholarly analysis. Use in connection with any form of information storage and retrieval, electronic adaptation, computer software, or by similar or dissimilar methodology now known or hereafter developed is forbidden.

The use in this publication of trade names, trademarks, service marks, and similar terms, even if they are not identified as such, is not to be taken as an expression of opinion as to whether or not they are subject to proprietary rights.

$\begin{array}{lllllllll}9 & 8 & 7 & 6 & 5 & 4 & 3 & 2 & 1\end{array}$

springer.com 


\section{Preface}

This book was conceived over dinner at the Cooloola Dunes near Brisbane, Australia, as we pondered how to reconcile 700,000 years of soil development with typical successional studies of $<200$ years and restoration concerns that normally cover $<20$ years. Restoration ecology is deeply rooted in ecological succession yet seems, as a fast-emerging discipline, to be largely unaware of the potential benefits a closer examination of succession can provide. These benefits address both how to restore ecosystem function and structure as quickly as possible and the longer-term consequences of current restoration activities. Successfully restored ecosystems can be more or less sustainable without constant care. This state is only achievable within a framework that recognizes, implicitly or explicitly, the temporal dynamics that constitute successional processes. While the current goals of restoration do not address change over thousands of years, certainly 2-200 year dynamics, the most common temporal scale for successional studies, are essential to consider. Restoration tactics will also differ depending on the age of the ecosystem being restored. Succession offers insights into processes of change in ecosystems of all ages, from very young, recently disturbed sites to very old systems such as the Cooloola Dunes.

Restoration ecology incorporates many areas of knowledge both within and outside traditional ecology. Succession often complements or reinforces these ties. Disturbance ecology is central to defining the physical limits for both succession and restoration. Landscape ecology, like restoration, operates within a spatial context and incorporates many ecosystems while succession offers more ecosystem-specific lessons. Studies of ecological assembly seek generalizations similar to succession and critical to the initiation of restoration. Invasion biology studies emerging ecosystems that both restoration and succession must address in a rapidly changing world. Studies of ecosystem health help define appropriate restoration goals but are rarely addressed in a successional context. Historical ecology provides proper land-use context for both restoration and succession. We argue that restoration within a successional framework will best utilize the lessons from each of these areas. Restoration, unlike successional studies, must cross disciplines and address societal needs, including politics, economics, human health issues, sustainability, and land-use planning.

Restoration also has much unfilled potential to elucidate fundamental unknowns within successional studies. When restoration is conducted within a 
scientific framework of replicated studies and peer-reviewed publication, it can clarify much about species change. Restoration is the acid test of our ability to understand not only how ecosystems are assembled and held together but also how they change over time. Proper documentation of both the failures and the successes of restoration activities will advance our understanding of many of the aforementioned subdisciplines of ecology, including succession, particularly within landscape gradients and novel, emergent ecosystems.

We assembled this book in order to examine and strengthen both the theoretical and practical ties between succession and restoration. We are not constrained by occasional differences in temporal or spatial scales between the two disciplines or the relative focus on natural versus human-managed ecosystems because restoration is fundamentally the management of succession. Restoration must ultimately succeed if disturbed landscapes are to be recovered and we argue that success will improve where successional principles are employed.

Lawrence was supported by a sabbatical from the University of Nevada Las Vegas, by Landcare Research in Lincoln, New Zealand, and by grants DEB0080538 and DEB-0218039 from the National Science Foundation, as part of the Long Term Ecological Research Program in Puerto Rico.

We wish to thank the external reviewers whose comments made our jobs easier. These generous people include: Joe Antos, Peter Bellingham, Lisa Belyea, Ray Callaway, Vic Claassen, Viki Cramer, Tim Ellis, Valerie Eviner, Tadashi Fukami Ari Jumpponen, Werner Härdtle, David Mackenzie, Scott Meiners, Robin Pakeman, Gert Rosenthal, Simon Veitch, Evan Weiher, and Sue Yates, Truman Young, Joy Zedler. In addition, most chapter authors contributed reviews of one or more chapters.

Writing and editing books inevitably takes us away from many urgent family matters. The editors express their appreciation for the patience and support given by our wives Elizabeth, Janet, and Gillian, and the Hobbs' children Katie and Hamish during the long course of working on this book.

Lawrence R. Walker Joe Walker Richard J. Hobbs 


\section{Contents}

Preface $\quad$ V

Contributing Authors $\quad$ ix

1. Forging a New Alliance Between Succession and Restoration 1 Lawrence R. Walker, Joe Walker, and Roger del Moral

2. Insights Gained from Succession for the Restoration of Landscape Structure and Function

Roger del Moral, Lawrence R. Walker, and Jan P. Bakker

3. Aboveground-Belowground Linkages, Ecosystem Development, and Ecosystem Restoration

David A. Wardle and Duane A. Peltzer

4. Retrogressive Succession and Restoration on Old Landscapes Joe Walker and Paul Reddell

5. Succession and Restoration of Drained Fens: Perspectives from Northwestern Europe

Joachim Schrautzer, Andreas Rinker, Kai Jensen, Felix Müller, Peter Schwartze, and Klaus Dierßen

6. Manipulation of Succession

Karel Prach, Rob Marrs, Petr Pyšek, and Rudy van Diggelen

7. Restoration as a Process of Assembly and Succession Mediated by Disturbance

Richard J. Hobbs, Anke Jentsch, and Vicky M. Temperton

8. Integrating Restoration and Succession

Richard J. Hobbs, Lawrence R. Walker, and Joe Walker

Glossary

Index 


\section{Contributing Authors}

Jan P. Bakker, Professor of Coastal Conservation Ecology, Community and Conservation Ecology Group, University of Groningen, PO Box 14, NL-9750 AA Haren, The Netherlands. j.p.bakker@ rug.nl Jan studies coastal ecosystems with a focus on the restoration and management of marshes and grasslands.

Rudy van Diggelen, Assistant Professor of Plant Ecology, Community and Conservation Ecology Group, University of Groningen, PO Box 14, 9750 AA Haren, The Netherlands. r.van.diggelen@ rug.nl Rudy studies community assembly and the functioning and restoration of degraded ecosystems.

Klauss Dierßen, Professor of Plant Ecology, Ecology Centre, University of Kiel, Olshausenstrasse 75, D-24118, Kiel, Germany. kdierssen@ecology. uni-kiel.de Klauss examines biodiversity, ecosystem functioning, and landscape planning.

Richard J. Hobbs, Professor of Environmental Science, School of Environmental Science, Murdoch University, Murdoch, WA 6150, Australia. r.hobbs@murdoch.edu.au Richard studies the management and restoration of altered ecosystems and landscapes.

Kai Jensen, Professor of Applied Plant Ecology, Population and Vegetation Ecology, Biocentre Klein Flottbek, University of Hamburg, Ohnhorststrasse 18, 22609 Hamburg, Germany. kai.jensen@botanik.uni-hamburg.de Kai's main interest is the vegetation of riparian and coastal wetlands and its relation to land-use as well as to abiotic site conditions and biotic interactions.

Anke Jentsch, Vegetation Ecologist, Centre for Environmental Research Liepzig, Department of Conservation Biology, UFZ, Permoserstr. 15, D-03418, Leipzig, Germany. anke.jentsch@ufz.de Anke's main research interests are in disturbance ecology, system dynamics, plant biodiversity, and ecosystem function.

Rob Marrs, Professor of Applied Plant Biology, Applied Vegetation Dynamics Laboratory, University of Liverpool, Liverpool L69 7ZB, United Kingdom. calluna@liverpool.ac.uk Rob's research interests focus on the manipulation of succession toward specified endpoints, specifically in heaths, moors, and bracken-dominated habitats. 
Roger del Moral, Professor of Biology, Department of Biology, University of Washington, 1521 NE Pacific St., Seattle, Washington 98195-5325, USA. moral@u.washington.edu Roger studies the recovery of systems after catastrophic disturbances and practices wetland restoration.

Felix Müller, Systems Ecologist, Ecology Centre, University of Kiel, Olshausenstrasse 75, D-24118, Kiel, Germany. fmueller@ecology. uni-kiel.de Felix Mueller is a systems ecologist whose main research interests are in ecosystem theory, ecological indicators, and landscape analysis.

Duane Peltzer, Research Scientist, Landcare Research, PO Box 69, Lincoln 8152, New Zealand. peltzerd@landcareresearch.co.nz Duane studies interactions among plants and soil communities along environmental gradients and quantifies plant impacts on ecological and ecosystem processes.

Karel Prach, Professor of Botany, Faculty of Biological Sciences, University of České Budějovice, Branišovská 31, CZ-370 01 České Budějovice, Czech Republic AND Researcher, Institute of Botany, Academy of Sciences of the Czech Republic, Třeboň. prach@bf.jcu.cz Karel's main research interests concern vegetation succession, plant invasions, and ecology of river floodplains, with emphasis on restoration aspects.

Petr Pyšek, Researcher, Institute of Botany, Academy of Sciences of the Czech Republic, CZ-252 43, Průhonice, Czech Republic, AND Associate Professor, Department of Ecology, Faculty of Science, Charles University, Viničná 7, CZ-128 01 Praha 2, Czech Republic. pysek@ibot.cas.cz Petr's research interests include general aspects of biological invasions, ecology of invasive plant species, factors determining species diversity, and vegetation succession.

Paul Reddell, Chief Scientist, Ecobiotics Ltd., P.O. Box 148, Yungaburra, Queensland, Australia. paul.reddell@ecobiotics.com.au Paul is a rainforest ecologist. He works for a company that searches for medical compounds in tropical rainforests. His research interests include rainforest dynamics and restoration of mined sites and tropical landscapes subjected to a wide range of disturbances.

Andreas Rinker, CEO, DygSyLand, Institute for Digital System Analysis and Landscape Diagnosis, Zum Dorfteich 6, 24975 Husby, Germany. rinker@digsyland.de Andreas' research interests focus on ecosystem modelling and landscape management.

Peter Schwartze, Geobotanist, Biologische Station Kreis Steinfurt e.V., Bahnhofstrasse 71, 49545 Tecklenburg, Germany. biologische.station. steinfurt@t-online.de Peter's main research interests are on long-term development and management of grassland ecosystems.

Joachim Schrautzer, Assistant Professor, Ecology Centre, University of Kiel, Olshausenstrasse 75, D-24118, Kiel, Germany. jschrautzer@ecology.unikiel.de Joachim's main research interests focus on the management and restoration of fen and grassland ecosystems.

Vicky Temperton, Plant Ecologist, Phytosphere Institute, Juelich Research Centre, D-52425 Juelich, Germany. v.temperton@fz-juelich.de Vicky works 
on plant community assembly and its relation to restoration ecology and disturbance, as well as its influence on plant biodiversity and ecosystem function.

Joe Walker, Research Fellow, CSIRO Land and Water, PO Box 1666, Canberra, ACT 2611, Australia. joe.walker@csiro.au Joe is an eco-hydrologist whose main research interests include assessments of catchment and landscape condition, restoration of degraded agricultural lands, fire management, succession theory, and ecological indicators.

Lawrence R. Walker, Professor of Biology, Department of Biological Sciences, University of Nevada Las Vegas, 4505 Maryland Parkway, Las Vegas, Nevada 89154, USA. walker@unlv.nevada.edu Lawrence studies mechanisms and theories of plant succession and restoration ecology, and emphasizes crosssite comparisons.

David Wardle, Professor of Ecology, Department of Forest Vegetation Ecology, Swedish University of Agricultural Sciences, SE901-83 Umeå, Sweden AND Research Scientist, Landcare Research, PO Box 69, Lincoln 8152, New Zealand.david.wardle@svek.slu.se David studies links between aboveground and belowground communities, drivers of ecosystem functions, and soil ecology. 